\title{
Hardness of cryolite, chiolite, cryolithionite and other fluorides from Ivigtut, South Greenland
}

\author{
HANS PAULY
}

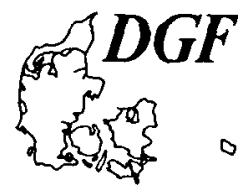

\begin{abstract}
Pauly, Hans: Hardness of cryolite, chiolite, cryolithionite and other fluorides from Ivigtut, South Greenland. Bull. Geol. Soc. Denmark, Vol. 34, pp. 145-150, Copenhagen, December, 19th, 1985. https://doi.org/10.37570/bgsd-1985-34-13

Chiolite has been found to be softer than cryolite which has the Mohs hardness $H=21 / 2-3$. Scratching tests indicate $\mathrm{H}=2 \frac{1}{2}$ for chiolite and not 4 as usually given in the literature. This observation lead to an exami-nation of a number of pure samples of fluorides from Ivigtut. Vickers hardness numbers (VHN) were de-termined on a number of these samples supplementing the Mohs hardness $(\mathrm{H})$. The following results were

obtained, italized $\mathrm{H}$-values are new. Chiolite $H=2^{1} / 2 \mathrm{VHN}_{25}=161$; cryolite $\mathrm{H}=2^{1} / 2-3 \mathrm{VHN}_{50}=286-346$; thomsenolite $H=3 \quad 3^{1} / 2 \mathrm{VHN}_{25}=274$; pachnolite $H=3-3^{1} / 2 \mathrm{VHN}_{50}=362$; weberite $\mathrm{H}=3^{1 / 2} \mathrm{VHN}_{50}=$ 362 ; jarlite $\mathrm{H}=3^{1 / 2-4}$; cryolithionite $H=4 \mathrm{VHN}_{50}=429$; metajarlite $\mathrm{H}=4-4 \frac{1}{2} \mathrm{VHN}_{50}=317$; prosopite $\mathrm{H}=4^{1 / 2}$ and ralstonite $H=5$.
\end{abstract}

Hans Pauly, Technical University of Denmark, Building 204, Lyngby DK-2800, Denmark. December 14th, 1984.

\section{Introduction}

Incidentally it was noted that mm-wide veins of cryolite in a polished block of chiolite stood out against the surrounding chiolite: the polishing hardness of cryolite was higher than that of chiolite. This is the reverse of the Mohs hardnesses attributed to the two minerals: cryolite $2 \frac{1}{2}-3$ and chiolite $3 \frac{1}{2}-4$. When the two minerals were tested against each other, cryolite was found to scratch chiolite but chiolite could not scratch cryolite. This observation lead to mutual scratching tests with a number of pure samples of fluorides from Ivigtut. The following order of succession was established going from softer to harder minerals:

chiolite

cryolite

thomsenolite, pachnolite

weberite

jarlite

cryolithionite

meta-jarlite

prosopite

ralstonite

As this sequence also revealed changes for other fluorides a revision of their Mohs hardnesses was obviously called for.
The steps of the Mohs scale involved here are 2, 3, 4 and 5 represented by halite, calcite, fluorite and apatite; Mohs 1822 noted that halite might proxy for gypsum. Seemingly straight forvard, the redetermination of the Mohs hardnesses was found to present some difficulties. The strong anisotropy of hardness exhibited by calcite is of particular importance here but it also raises a more general question for the practical establishment of hardness 3 . Some comments will be given below in order to demonstrate the solution chosen here. Other difficulties appear when results obtained on crystal faces are compared with results obtained on finegrained aggregates of a mineral. Problems are also related to the type of surface tested on the mineral in question: whether it is a natural cleavage face, a crystal face or a polished surface. Further problems in determination of Mohs hardnesses can be listed but the nature of these determinations certainly warns against exaggeration.

Mohs (1822) regarded testing through mutual schratching as being insufficient when a finer graduation was sought. $\mathrm{He}$ recommended striking the unknown mineral on a file in order to compare the effect with that of striking those minerals of his hardness scale which came closest to the unknown. Trøger (1954) discussed some of the relevant problems. Here it may be enough to 
mention that in testing through scratching it is important to test both minerals against each other.

In spite of all limitations, experience shows the practical value of the Mohs hardness in dealing with minerals and it is generally acknowledged that values in between the steps of the scale can be established. Conventionally they are quoted as $\mathrm{X} 1 / 2$. A further subdivision is in fact considered feasible when a hardness is given as $\mathrm{X}-\mathrm{X} 1 / 2$ or $\mathrm{X}^{1 / 2}-\mathrm{Y}$ meaning that the hardness is closer to either $\mathrm{X}$ or $\mathrm{Y}$.

Before reporting the Mohs hardness values obtained on the mentioned fluorides some considerations concerning the hardness of calcite are presented.

Supplementing these hardness determinations, Vickers hardness numbers (VHN) were established for several of the examined fluorides. It must be stressed, however, that the accuracy of these determinations is reduced because of the extremely low reflectances of the involved minerals. It is probably not better than $\pm 10 \%$. In carrying out these determinations it is important to note that only absolutely pure samples could be used. From refractive indices it can be calculated that cryolite and cryolithionite both have the reflectance $2.1 \%$ and chiolite 2.2 . It is thus impossible to distinguish these minerals in the microscope during the testing.

For comparison VHN determinations were performed on halite, calcite and fluorite, representing the Mohs hardness values, 2, 3 and 4.

\section{Calcite and hardness 3}

It is well known and often cited in manuals on crystallography and mineralogy that the cleavage faces of calcite show pronounced anisotropy of scratching hardness, see e.g. Raaz and Tertsch (1958). The lowest hardness is observed on (1011) when scratching up towards the c-axis along the diagonal of the rhombe shaped face (connecting the obtuse angles). A piece of silver can only scratch calcite along this direction. The greatest hardness of (1011) is obtained in the opposite direction. Calcite itself can not produce a scratch in this direction, but in the directions perpendicular to this direction it can produce a faint scratch.

The hardnesses of the prism faces of calcite are greater. Fluorite was found to produce a scratch across $(10 \overline{1} 0)$ but not in the direction parallel to the c-axis. According to a quotation from Rosiwal in Raaz and Tertsch (1958), the grinding hardness of the prism (1120) is even larger than that of $(10 \overline{1} 0)$.

For the minerals studied here it was assumed that their hardness was above 3 if they could produce scratches in all directions on a cleavage face of a piece of Iceland spar which is chemically very pure calcite. If they only produced scratches up towards the $c$-axis their hardness was rated below 3 (but above $2 \frac{1}{2}$ because the value $2 \frac{1}{2}-3$ is given to silver).

Cryolite

d'Andrada (1800) reported for cryolite: "Er ritset den Kalkspath und lässt sich vom Flussspathe rissen", and this is quoted by Abildgaard (1801). Schumacher (1801) noted that cryolite is "halbhart" a hardness characteristic also given to calcite. Mohs (1821) gave the hardness of cryolite as $2 \frac{1}{2}-3$ and this is repeated in Mohs (1822) where he gave details about his 10 -step hardness scale. It might further be mentioned that Breithaupt (1841) gave cryolite the hardness $3 \frac{1}{2}-4$ but this referred to a 12-step scale in which he had inserted extra steps between no. 2 and 3 and no. 5 and 6 of Mohs scale, Naumann (1871).

These results were obtained on massive, white cryolite the only type known at that time.

The prismatic parting of massive cryolite indicates that this variety of the mineral consists of $\mathrm{dm}$ to $\mathrm{m}$-sized grains but it is transsected by numerous twin lamellae belonging to several different twin laws. These lamellae may be less than $0.1 \mathrm{~mm}$ thick (Pauly 1978). Polished surfaces of this material can be faintly scratched by calcite. On a cleavage face of this mineral, massive cryolite is found to produce a scratch only in the direction towards the $c$-axis along the diagonal of the rhomb connecting the obtuse angles. In the opposite direction and perpendicular to this direction massive cryolite cannot scratch the calcite.

This, taken together with the observation that cryolite easily scratches halite (the reverse is not the case) strongly supports Mohs result: $2 \frac{1}{2}-3$ is the hardness of massive cryolite.

Cryolite crystals, however, were found to pro- 
duce scratches in all directions on the cleavage face of calcite but they could not produce scratches on fluorite or crystal faces of thomsenolite and pachnolite. These observations indicate that cryolite crystals are harder than massive cryolite. This may be related to the different twin patterns: massive cryolite being transsected by numerous twin lamellae corresponding to five to seven different twin laws whereas the crystals usually contains only one or two twins (Bøggild 1912, Pauly 1978). Because calcite itself cannot produce a scratch in the hardest direction on (10ī1) and crystals of cryolite can produce a faint scratch in this direction (thomsenolite and pachnolite do it easier) the Mohs hardness $3-3 \frac{1}{2}$ seems appropriate for crystals of cryolite.

Vickers hardness tests on polished samples of the massive cryolite gave $\mathrm{VHN}_{25}=262(254$ $274)^{6}$ (here and in the following this means minimum 254, maximum 274 in 6 determinations) and $\mathrm{VHN}_{50}=286(256-375)^{6}$. Determinations on three (110) faces of 3-5 mm big crystals gave $\mathrm{VHN}_{25}=279(236-322)^{7}$ and $\mathrm{VHN}_{50}=306(286-$ $320)^{9}$. It is a well established fact that the microhardness decreases with increase in the applied load, see e.g. Young and Millman 1963-64. The here obtained lower values of $\mathrm{VHN}_{25}$ as compared with the values of $\mathrm{VHN}_{50}$ may reflect variations in orientations caused by the presence of lamellae of polysynthetic twins Pauly 1978. As these lamellae can not be distinguished in reflected light microscopy a much higher number of determinations would be needed in order to clarify this matter. On (001) faces of three crystals were found $\mathrm{VHN}_{25}=411(350-464)^{24}$ and $\mathrm{VHN}_{50}$ $=346(286-412)^{31}$.

\section{Cryolithionite}

Ussing 1904 stated "La dureté de la cryolithionite est comprise entre 2.5 et 3 ". This is difficult to understand because the mineral easily scratches calcite in all directions on the cleavage face. Winchell \& Winchell 1964 gave the hardness as $31 / 2-4$.

It is found that cryolithionite can produce faint scratches on (111) faces of a fluorite crystal and on a polished face cut parallel to (100) of the fluorite. Fluorite produces scratches with difficulty on a polished surface of cryolithionite. This, taken together with the results of testing the cryolithionite against other fluorides from Ivig- tut, seems to indicate that the Mohs hardness of cryolithionite should be taken as 4 .

Vickers hardness determinations on a polished sampled of cryolithionite gave $\mathrm{VHN}_{50}=429$ $(385-473)^{9}$.

\section{Chiolite}

Hermann (1846) characterised the hardness of chiolite thus: "Härte des Flussspaths", i.e. $\mathrm{H}=4$. $\mathrm{He}$ also mentioned that the density was 2.72 . Nordenskiöld (1886) in examining a sample of "arksutite" (Hagemann 1866) from Ivigtut found it to consist of a mixture of fluorite and chiolite. He estimated the hardness of the chiolite to "ungefär 3".

Tests show that massive cryolite can easily scratch chiolite on its cleavage face (001) and on polished faces cut parallel to (hk0).

Chiolite cannot scratch cryolite and calcite but faintly scratches halite on a (100) face. It is found reasonable to attribute the hardness $2 \frac{1}{2}$ to chiolite.

Hermann (1846), in describing the new mineral that he and Dr. Auerbach detected in a topaz mine in the district of Miask, Urals, mentioned that "Der Chiolith ist gewöhnlich derb. Er besteht seiner Hauptmasse nach aus körnig krystallinischen Theilen, wird aber stellenweise späthig und blättrig-krystallinisch".

Bøggild (1913) reported new observations made on material from Ivigtut as well as observations made on samples from Miask, not only found in Copenhagen but also in the collections in Stockholm, Heidelberg and München. $\mathrm{He}$ noted from these examinations: "Es scheint also der recht merkwürdige Fall zu sein, dass beinahe alles Material, dass in den Sammlungen als Chiolith von Ural etikettiert liegt, hauptsächlich aus den beiden genanten Mineralien [Kryolith und Kryolithionit] besteht, während der Chiolith selbst eine verhältnismässig untergeordnete Rolle spielt".

From this one might be inclined to think that Hermann in establishing the properties of the new mineral chiolite happened to work on pieces of cryolithionite. The density given by Hermann as 2.72 is fairly close to that of cryolithionite (2.77) whereas it is rather far from that of chiolite (3.00). However, his material for chemical analy- 
sis probably did not contain cryolithionite as he mentioned that no traces of $\mathrm{K}$ or $\mathrm{Li}$ were found.

Vickers hardness tests on polished samples of chiolite, one cut parallel to the c-axis and one containing several differently oriented grains, gave $\mathrm{VHN}_{25}=161(122-206)^{13}$.

\section{Thomsenolite}

Dana (1868) noted for thomsenolite the hardness 2.5-4. Bøggild (1953) noted the hardness to be 3 and remarked "in most manuals it is given as 2 , which is surely not correct".

Tests with calcite and fluorite seem to indicate the hardness for thomsenolite to be 3-31/2.

Vickers hardness determinations on a polished (001) cleavage face of a cm-large crystal, gave VHN $_{25}=274(220-320)^{8}$. The indentations were not quite satisfactory due to fracturing. With higher loads it was not possible to obtain useable indentations.

\section{Pachnolite}

The hardness for pachnolite is usually given as 3 but tests show that it easily scratches (1011) of calcite in all directions. It is clearly softer than fluorite. A cleavage face of thomsenolite can be scratched by pachnolite but not the prism faces. A hardness of 3-31/2 seems reasonable for pachnolite.

Vickers hardness determinations could not be carried out on a polished (001) face because of fracturing around the indentations. A polished sample of an aggregate of radiating, cm-long, mm-wide crystals, elongated after the c-axis, gave $\mathrm{VHN}_{25}=464^{2}$ and $\mathrm{VHN}_{50}=362(340-386)^{6}$.

\section{Weberite}

On the usual dense aggregates consisting of mmsized grains Bøgvad (1938) found for weberite the hardness $3 \frac{1}{2}$. This is in keeping with the results of tests with calcite and fluorite and the observation that weberite can produce scratches on the polished sample of the radiating pachnolite aggregates.

Vickers hardness determinations on a polished sampled of weberite gave $\mathrm{VHN}_{50}=362(306-$ $386)^{10}$.
Jarlite-metajarlite

Bøgvad (1933) found that the hardness of jarlite was probably $3-4$. Tests with aggregates of $\mathrm{mm}$ sized jarlite crystals show that the mineral can scratch calcite in all directions on the (1011) cleavage face. It cannot scratch fluorite but the polished sample of weberite is faintly scratched by jarlite. It seems that jarlite in the form of the mm-sized crystals has the hardness $31 / 2-4$.

Metajarlite occurs as dense masses which in the microscope are seen to consist of interfingering dendrites. Bøgvad (1933) noted the hardness of metajarlite to be $4-4 \frac{1}{2}$. This is confirmed through tests with fluorite and apatite. Metajarlite also scratches the polished surface of cryolithionite.

Vickers hardness determinations on two polished samples of metajarlite gave $\mathrm{VHN}_{50}=317$ (286-386) ${ }^{7}$.

\section{Prosopite}

Tests between aggregates of mm-sized crystals of prosopite from Ivigtut and fluorite and apatite indicated the hardness of the mineral to be about $4 \frac{1}{2}$ as is also given in the textbooks.

\section{Ralstonite}

In literature ralstonite is noted as having the hardness $4 \frac{1}{2}$. Tests with broken off pieces on an apatite crystal seemed to show ralstonite to have the same hardness as apatite, i.e. 5. This result was found both for ralstonite crystallised as cubes modified by small faces of the octahedron and for crystals dominated by the octahedron with only small truncating cube faces (Pauly 1965).

\section{Concluding remarks}

Table 1 summarizes the results obtained in the present study. It is seen that the Mohs hardnesses and the Vickers hardness numbers place chiolite as the softest and cryolithionite as the hardest with cryolite in-between. The VHN values obtained on (110) and (001) faces of cryolite indicate an interestingly high anisotropy. In a general way the VHN determinations also confirm the Mohs hardnesses for pachnolite and weberite. 
Table 1. Mohs $\mathbf{H}$ and VHN observed for fluorides from Ivigtut, South Greenland. VHN and Mohs $\mathbf{H}$ calculated using the relation $\mathbf{H}=$ $(\text { VHN } \cdot 0.1)^{0.4}$ from Young \& Millman (1963-64). For comparison VHN and Mohs H are given after Povarennykh \& Lebedeva (1970).

\begin{tabular}{|c|c|c|c|c|c|c|c|c|c|c|}
\hline \multirow[b]{2}{*}{$\begin{array}{c}\text { Mohs } \\
\text { H }\end{array}$} & & \multirow[b]{2}{*}{$\begin{array}{l}\text { VHN } \\
\text { calc. }\end{array}$} & \multirow[b]{2}{*}{ Mineral } & \multirow[b]{2}{*}{$\begin{array}{c}\text { VHN } \\
25\end{array}$} & \multirow[b]{2}{*}{$\begin{array}{l}\text { Mohs } \\
\text { calc. }\end{array}$} & \multirow[b]{2}{*}{$\begin{array}{l}\text { VHN } \\
50\end{array}$} & \multirow{2}{*}{ Mohs } & \multicolumn{3}{|c|}{$\begin{array}{l}\text { Povarennykh \& } \\
\text { Lebedeva (1970) }\end{array}$} \\
\hline & & & & & & & & $\begin{array}{l}\text { VHN } \\
20\end{array}$ & $\begin{array}{l}\text { VHN } \\
50\end{array}$ & $\begin{array}{c}\text { Mohs } \\
\text { H }\end{array}$ \\
\hline $2 \frac{1}{1} / 2$ & & 99 & Chiolite & 161 & 3.0 & & & 253,6 & & 4.5 \\
\hline \multirow[t]{3}{*}{$21 / 2-3$} & & 125 & Cryolite massive & 262 & 3.7 & 286 & 3.8 & 198.5 & & 4 \\
\hline & & & Cryolite (110) & 279 & 3.8 & 306 & 3.9 & & & \\
\hline & & & Cryolite (001) & 411 & 4.4 & 346 & 4.1 & & & \\
\hline $3-3^{1 / 2}$ & & 190 & Thomsenolite $^{1}$ & 274 & 3.76 & & & 238.8 & & 4 \\
\hline $3-3^{1 / 2}$ & & 190 & Pachnolite $^{2}$ & 464 & 4.6 & -362 & 4.2 & 248.5 & & 4.5 \\
\hline $3 \frac{1}{2}$ & & 238 & Weberite & & & 362 & 4.2 & & 277.3 & 4.7 \\
\hline 4 & & 320 & Cryolithionite & & & 429 & 4.5 & 227.5 & & 4 \\
\hline $4-4^{1} / 2$ & & 372 & Meta-jarlite & & & 317 & 4.0 & & & \\
\hline $4^{1 / 2}$ & & 430 & Prosopite & & & & & & 332.5 & 4.9 \\
\hline 5 & : & 559 & Ralstonite & & & & & & 361.3 & 5 \\
\hline
\end{tabular}

1 (001) used in the present study for VHN determinations.

${ }^{2}$ (hk0) used in the present study for VHN determinations.

For metajarlite the VHN value is seen to be too low; this may be caused by the numerous vacuoles present in this mineral although the $17 \mu \mathrm{m}$ indentations did not show significant deformations.

The VHN values here obtained seem rather high compared to the values obtained from calculations based on the formula given by Young and Millman (1963-64): Mohs $\mathrm{H}=(\mathrm{VHN} / 10)^{0.4}$. VHN determinations carried out on halite, calcite and fluorite were as follows. On a cleavage face of halite $\mathrm{VHN}_{25}=18.9^{4}$. A polished (0001)face on calcite (Iceland spar) gave $\mathrm{VHN}_{15}=166$ $(158-178)^{5}$ and $\mathrm{VHN}_{25}=131(128-151)^{7}$; a cleavage face (10ī1) gave $\mathrm{VHN}_{25}=181(143-206)^{7}$. On a polished (100)-face of fluorite $\mathrm{VHN}_{50}=$ $175^{4}$ was found. For halite and fluorite these values agree well with the values reported by Young and Millman (1963-64): halite VHN $_{25}=19-21$ and fluorite, (100): $\mathrm{VHN}_{100}=174-181$. For calcite they reported for (1011): $\mathrm{VHN}_{25}=127-146$ which seems somewhat lower than the values obtained in the present study.

Although the present examination of some fluorides from Ivigtut was not aimed at a deeper understanding of the relations between the Vickers hardnesses and the Mohs hardness steps from $2 \frac{1}{2}$ to 4 , it seems to indicate that the relations are more complicated than expressed by the formula proposed by Young and Millman (1963-64) or other similar formulae. It seems clear that the fluorides examined here do not represent mate- rial suitable for such a study because their extremely low reflectances prevent safe identifications during the work and the measurements of the indentation sizes are difficult because of the low contrasts. These factors are assumed to explain at least part of the deviations between the VHN values here obtained and those reported by Povarennykh and Lebedeva (1970), given in Table 1 . The basis for the Mohs hardnesses they reported is not clear.

Acknowledgments. I wish to express warm thanks to Erik Kristiansen M.Sc., librarian at the Geological Museum, Copenhagen University, for his kind and competent assistance in tracing several of the early publications needed for the present study. J. Bailey, Ph.D. kindly corrected the English of the text.

\section{Dansk sammendrag}

I en poleret blok af kiolit med årer af kryolit viste det sig at kryoliten stod frem i relief mod kioliten. Kryolitens polerhảrdhed var altså st $ø$ rre end kiolitens. Da kiolit angives at have ridsehårdheden, Mohs hărdheden $\mathbf{H}=4$ medens kryolit har $\mathrm{H}$ $=2 \frac{1}{2}-3$ var det markeligt. Ridseprøver viste for kiolit $\mathbf{H}=2 \frac{1}{2}$. Undersøgelser af en række andre fluorider fra Ivigtut suppleret med Vickers hårdhedsbestemmelser på flere af dem gav følgende resultater:

Kiolit $H=2^{l} / 2 \mathrm{VHN}_{25}=161 ;$ kryolit $\mathrm{H}=2^{1} / 2-3 \mathrm{VHN}_{50}=$ 286-346; thomsenolit $H=3-3^{I} / 2 \mathrm{VHN}_{25}=274$; pachnolit $H=$ $3-3^{1} / 2$ VHN $_{50}=362$; weberit $\mathbf{H}=3 \frac{1}{2}$ VHN $_{50}=362$; jarlite $\mathbf{H}$ $=3^{1} / 2-4 ;$ kryolithionit $H=4 \mathrm{VHN}_{50}=429$; metajarlit $\mathbf{H}=$ $4-4^{1} / 2 \mathrm{VHN}_{50}=317$; prosopit $\mathrm{H}=4^{1} / 2$ og ralstonit $H=5$. De kursiverede er nye vardier.

Det er vanskeligt at forstå hvorfor Ussing 1904 har givet kryolithionit hårdheden $2 \frac{1}{2}-3$ d.v.s. som kryolit. For kiolits vedkommende synes forklaringen at være at Hermann (1846), der beskrev mineralet fra en topasforekomst i Ural, har forvekslet 
det med kryolithionit ved ridseprøven, thi Bøggild (1913) skrev, at hans undersøgelser havde vist at kiolitprøverne fra Ural i samlingerne i såvel København som i Stockholm, Heidelberg og München hovedsagelig indeholdt kryolit og kryolithicnit medens kiolit kun var til stede i underordnet mangde.

\section{References}

Abildgaard, P. C. 1801: Om norske Titanertser og om en nye Steenart fra Grønland, som bestaar af Flusspatsyre og Alunjord. Vid. Selsk. Skr. Bd. 3, 1.1.pp. 306-316, København.

d'Andrada, J. B. 1800: Nachrichten von einigen neuen Fossilien aus Schweden und Norwegen; 11) Chryolit. Allgemeines Journal der Chemie. Herausgeg. v. Alexander Nicolas Scherer, Bd. 4, p. 37-38. Leipzig.

Breithaupt, A. 1841: Mineralogie II p. 200-201, Arnoldische Buchhandlung, Dresden und Leipzig.

Bøggild, O. B. 1912: Krystalform und Zwillingsbildungen des Kryoliths, des Perowskits und des Boracits. Zeitschrift f. Krystallogr. 50, pp. 349-429.

Bøggild, O. B. 1913: Beobachtungen über die Mineralien der Kryolithgruppe. Zeitschrift f. Krystallogr. 51, pp. 591-613.

Bøggild, O. B. 1953: The Mineralogy of Greenland. Meddelelser om Grønland Bd. 143, p. 95.

Bøgvad, R. 1933: New Minerals from Ivigtut, Southwest Greenland. Meddelelser om Grønland, Bd. 92, Nr. 8, pp. 1-11.

Bøgvad, R. 1938: Weberite, a New Mineral from Ivigtut. Meddelelser om Grønland, Bd. 119, Nr. 7, pp. 1-11.

Dana, J. D. 1868: A System of Mineralogy. Descriptive Mineralogy. 5. Ed. Trübner \& Co. London, p. 129.

Hagemann, G. 1866: On some minerals associated with the Cryolite in Greenland. The American Journal of Science and Art. Second Series, Vol. XLII, No. 124, Art. XV, p. 93-94.
Hermann, A. 1846: Untersuchungen russischer Mineralien 26) Ueber Chiolith, ein neues Mineral. Journal für praktische Chemie, Vol. 37, pp. 188-190.

Mohs, F. 1821: Die Charaktere der Klassen, Ordnungen, Geschlechter und Arten, oder die Characteristik des naturhistorischen Mineral = Systemes. Zweite, verbesserte Auflage. Der Arnoldischen Buchhandlung, Dresden.

Mohs, F. 1822: Grundriss der Mineralogie. Arnoldischen Buchhandlung, Dresden, p. 533.

Naumann, C. F. 1871: Elemente der Mineralogie. 8. Auflage. Verlag von Wilhelm Engelmann, Leipzig, p. 103.

Palache, C., Berman, H. \& Frondel, C. 1951: Dana's System of Mineralogy (7th ed.), II. John Wiley \& Sons, New York, pp. 99-128

Pauly, H. 1978: Twins in cryolite types from Ivigtut, South Greenland. Bull. Geol. Soc., Denmark, Vol. 27, Special Issue, pp. 7-14.

Pauly, H. 1965: Ralstonite from Ivigtut, South Greenland. Am. Min. Vol. 50, pp. 1851-1864.

Povarennykh, A. S. and Lebedeva, A. D. 1970: The infrared absorption and microhardness of the most important aluminofluorides. Dop. Akad. Nauk. Ukr. RSR, Kiev, Ser. B (1), p. 31-34, (In Russian).

Schumacher, C. F. 1801: Versuch eines Verzeichnisses der in den Dänisch-Nordischen Staaten sich findenden einfachen Mineralien. Friedrich Brummer, Kopenhagen, pp. 103-104.

Tröger, E. 1954: Zur Kritik der Härteskala nach Mohs. Neues $J b$. Mineral. Mh. 11, pp. 233-242.

Ussing, N. V. 1904: Sur la cryolithionite, espéce minérals nouvelle. Bull de l'Academie Royale des Sciences et des Lettres de Danemark, No. 1, pp. 1-12.

Winchell, A. N. and Winchell, H. 1964: Elements of optical mineralogy. 4th Ed. Part II, John Wiley \& Sons Inc. New York, p. 33.

Young, B. B. and Millman, A. P. 1963-64: Microhardness and Deformation of Ore Minerals. Transactions of the Institution of Mining and Metallurgy, Vol. 73, part 7, pp. 437447. 